\title{
Hepatic Bilirubin Uptake in the Isolated Perfused Rat Liver is Not Facilitated by Albumin Binding
}

\author{
Yacov R. Stollman, Ulrich Gärtner, Lorenz Theilmann, NaOhito Ohmi, and \\ Allan W. Wolkoff, Department of Medicine and Liver Research Center, \\ Albert Einstein College of Medicine, Bronx, New York 10461
}

\begin{abstract}
A B S T R A C T Bilirubin uptake by the liver is a rapid process of high specificity that has kinetic characteristics which suggest carrier-mediation. In the circulation, bilirubin is readily bound to albumin, from which it is extracted by the liver. Although several studies suggested that it is the small, unbound fraction of bilirubin which interacts with hepatocytes and is removed from the circulation, recent experiments have been interpreted as suggesting that binding to albumin facilitates ligand uptake. A liver cell surface receptor for albumin has been postulated. The present study was designed to examine directly whether albumin facilitates the hepatic uptake of bilirubin and whether uptake of bilirubin depends on binding to albumin. Rat liver was perfused with a protein-free fluorocarbon medium, and single-pass uptake of 1,10 , or $200 \mathrm{nmol}$ of $\left[{ }^{3} \mathrm{H}\right]$ bilirubin was determined after injection as an equimolar complex with ${ }^{125} \mathrm{I}$-albumin, with ${ }^{125}$ I-ligandin, or free with only a $\left[{ }^{14} \mathrm{C}\right]$ sucrose reference. Uptake of $10 \mathrm{nmol}$ of $\left[{ }^{3} \mathrm{H}\right]$ bilirubin was $67.5 \pm 3.7 \%$ of the dose when injected with ${ }^{125} \mathrm{I}$-albumin, $67.4 \pm 6.5 \%$ when injected with ${ }^{125} \mathrm{I}$-ligandin, and $74.9 \pm 2.4 \%$ when injected with $\left[{ }^{14} \mathrm{C}\right]$ sucrose $(P>0.1)$. At $200 \mathrm{nmol}$, uptake fell to $46.4 \pm 3.1 \%$ ( ${ }^{125}$ I-albumin) and $63.3 \pm 3.4 \%\left(\left[{ }^{14} \mathrm{C}\right]\right.$ sucrose $)$ of injected $\left[{ }^{3} \mathrm{H}\right]$ bilirubin $(P<0.01)$, which suggests saturation of the uptake mechanism. When influx was quantitated by the model of Goresky, similar results were obtained. When $\left[{ }^{3} \mathrm{H}\right]$ bilirubin was injected simultaneously with equi-
\end{abstract}

A preliminary report of this work was presented at the 3lst meeting of the American Association for the Study of Liver Diseases, Chicago, IL, and appeared in abstract form in Gastroenterology, 1980, 79:1068.

Drs. Gartner and Theilmann are recipients of fellowships from the Deutsche Forschungsgemeinschaft. Dr. Ohmi's present address is Department of Medicine, Sapporo University, Sapporo Hokkaido, Japan.

Received for publication 17 July 1981 and in revised form 11 February 1983. molar ${ }^{125} \mathrm{I}$-albumin and a $\left[{ }^{14} \mathrm{C}\right]$ sucrose reference, there was no delay in ${ }^{125} \mathrm{I}$-albumin transit as compared with that of $\left[{ }^{14} \mathrm{C}\right]$ sucrose. This suggested that the off-rate of albumin from a putative hepatocyte receptor would have to be very rapid, which is unusual for high affinity receptor-ligand interaction. There was no evidence for facilitation of bilirubin uptake by binding to albumin or for interaction of albumin with a liver cell surface receptor. These results suggest that the hepatic bilirubin uptake mechanism is one of high affinity which can extract bilirubin from circulating carriers such as albumin, ligandin, or fluorocarbon.

\section{INTRODUCTION}

Bilirubin circulates bound to albumin at one high-affinity site and two or more lower affinity sites $(1,2)$. Bilirubin is rapidly removed from the circulation and enters the hepatocyte, where it is conjugated with glucuronic acid and excreted into bile $(3,4)$. Albumin does not enter the hepatocyte but remains in the circulation (5-9). Previous studies suggested that the unbound, rather than the bound, fraction of circulating bilirubin determines its uptake (10-13); the proposed role of albumin-binding is to solubilize the relatively hydrophobic bilirubin molecule, and thereby prevent nonspecific passage into other tissues, particularly the brain. A more specific role for albumin binding has recently been postulated in taurocholate and oleate uptake by the liver. Luxon and Forker suggested that release of taurocholate from albumin at the hepatocyte surface occurs at a faster rate than in the systemic circulation (14); a cell surface-mediated conformational change in albumin was postulated which accelerates dissociation of the albumin-taurocholate complex. In other studies, Weisiger et al. suggested that uptake of albumin-bound compounds is mediated by a receptor for albumin on the liver cell surface $(15,16)$. 
Although these studies present the intriguing idea that hepatic uptake of bilirubin is mediated by a liver cell surface receptor for albumin, they are indirect and depend on critical assumptions, both implicit and explicit, concerning ligand-albumin interaction that include binding affinity, number of binding sites, and dissociation rate constants. The present study was designed to determine directly whether albumin facilitates the hepatic uptake of bilirubin and whether uptake of bilirubin depends on binding to albumin. In these studies, rat liver was perfused with a proteinfree fluorocarbon medium, and uptake of $\left[{ }^{3} \mathrm{H}\right]$ bilirubin was determined after injection as an equimolar complex with ${ }^{125} \mathrm{I}$-albumin, with ${ }^{125} \mathrm{I}$-ligandin, or free with only a $\left[{ }^{14} \mathrm{C}\right]$ sucrose reference. Previous studies have demonstrated that sucrose remains in the extracellular space and is not taken up appreciably by the liver during the course of a single pass (17).

\section{METHODS}

Perfusion of isolated livers. Male Sprague-Dawley rats $(225-325 \mathrm{~g})$ were obtained from Charles River Breeding Laboratories, Inc., Wilmington, MA. After pentobarbital anesthesia $(4 \mathrm{mg} / 100 \mathrm{~g}$ body wt i.p.), the portal vein and inferior vena cava were rapidly catheterized. The liver was perfused in situ in a temperature-controlled cabinet at $37^{\circ} \mathrm{C}$ with 10\% fluorocarbon (Fluosol-43, Alpha Therapeutics Corp., Santa Ana, CA) in Krebs-Henseleit buffer containing $0.1 \%$ glucose. Viability of the liver was assessed by gross appearance and perfusate flow, perfusion pressure, aspartate amino-transferase release into perfusate, and hepatic $\mathrm{O}_{2}$ consumption.

$\left[{ }^{3} \mathrm{H}\right]$ Bilirubin (sp act, 100 or $33 \mathrm{mCi} / \mathrm{mmol}$ ) was prepared from dog bile after intravenous administration of delta $\left[{ }^{3} \mathrm{H}\right]-$ aminolevulinic acid (18) (Schwarz/Mann Div., Beckon Dickinson Immunodiagnostics, Orangeburg, NY; $60.2 \mathrm{Ci} / \mathrm{mmol}$ ). Ligandin was purified to homogeneity as previously described (19) and iodinated with $\mathrm{Na}{ }^{125} \mathrm{I}$ by a chloramine $\mathrm{T}$ method followed by Sephadex G-25 chromatography (20). ${ }^{125}$ I-albumin (bovine serum albumin [BSA]) and $\left[{ }^{14} \mathrm{C}\right]$ sucrose were purchased from New England Nuclear, Boston, MA. BSA, fraction V, was obtained from Sigma Chemical Co., St. Louis, MO.

Multiple indicator dilution studies. Studies were performed at any of three bilirubin concentrations: 1,10 , or $200 \mathrm{nmol} / 0.16 \mathrm{ml}$ injection. $\left[{ }^{3} \mathrm{H}\right] \mathrm{Bilirubin}(\simeq 1 \mu \mathrm{Ci})$ was dissolved in $0.05 \mathrm{ml}$ of hot $0.05 \mathrm{~N} \mathrm{NaOH}$, and then $0.05 \mathrm{ml}$ of Krebs-Henseleit buffer was added. In studies of high dose bilirubin uptake, the specific activity was diluted approximately 10-fold with unlabeled bilirubin (Sigma Chemical Co.). An appropriate mixture of radioactive ( ${ }^{125}$ I-labeled) and nonradioactive protein was added so that the ratio of bilirubin/protein was $1: 1$. Alternatively, in protein-free studies, $\left[{ }^{14} \mathrm{C}\right]$ sucrose was added as a nontransported reference. After a $30-\mathrm{min}$ stabilization period of perfusion, a 0.16 $\mathrm{ml}$ bolus of $\left[{ }^{3} \mathrm{H}\right]$ bilirubin $(0.5-1.0 \mu \mathrm{Ci})$ and reference $(0.2-$ $0.4 \mu \mathrm{Ci}$ ) was injected into the portal vein. All perfusate was collected from the hepatic vein in vials at 1-2-s intervals for $40 \mathrm{~s}$. The content of ${ }^{14} \mathrm{C}$ and ${ }^{3} \mathrm{H}$ in samples was determined in a liquid scintillation counter (model SL40, Intertechnique, Dover, $\mathrm{NJ}$ ) after addition of $10 \mathrm{ml}$ of Hydrofluor (National Diagnostics, Inc., Advanced Applications Institute Inc., So- merville, NJ). Content of ${ }^{125} \mathrm{I}$ was determined in a Packard gamma counter (Packard Instrument Co., Inc., Downers Grove, IL). Appropriate crossover and quench corrections were made.

To ascertain that bilirubin remained bound to albumin in the presence of fluorocarbon, circular dichroism was performed using a Cary model 60 spectropolarimeter (Varian Associates, Instrument Division, Palo Alto, CA) with a 6,000 CD attachment (1). The temperature of the cell compartment was $25^{\circ} \mathrm{C}$ and a cell of $1-\mathrm{mm}$ path length was used. The ellipticity pattern of a solution of $140 \mu \mathrm{M}$ bovine albumin and $70 \mu \mathrm{M}$ bilirubin in Krebs-Henseleit buffer was determined at wavelengths between 350 and $550 \mathrm{~nm}$. Onehalf of the volume contained in the cuvette was removed and an equal volume of $10 \%$ fluorocarbon solution was added and mixed. The ellipticity pattern was again determined.

Analysis of indicator dilution curves. Data were analyzed by the flow-limited diffusion model of Goresky $(6,21-$ 23). This is defined by the equation:

$$
\begin{aligned}
& C_{\text {bili }}(t)=\mathrm{e}^{-k_{1} t} C_{\text {ref }}(t)+\mathrm{e}^{-\left(k_{2}+k_{s}\right) t} \\
& \times \int_{0}^{t} \mathrm{e}^{-\left(k_{1}-k_{2}-k_{3}\right) r} C_{\text {ref }}\left(t^{\prime}\right) \times \sum_{n=1}^{\infty} \frac{\left(k_{1} k_{2} t^{\prime}\right)^{n}\left(t-t^{\prime}\right)^{n-1}}{n !(n-1) !} \mathrm{d} t^{\prime} .
\end{aligned}
$$

In this equation, $C_{\mathrm{bili}}(t)$ is the concentration of $\left[{ }^{3} \mathrm{H}\right]$ bilirubin in the effluent at time $t, C_{\text {ref }}(t)$ is the concentration of its nontransported reference ${ }^{125}$ I-albumin, ${ }^{125}$ I-ligandin, or $\left[{ }^{14} \mathrm{C}\right]$ sucrose), $k_{1}$ is the apparent influx rate constant, $k_{2}$ is the efflux rate constant, and $k_{3}$ is the sequestration rate constant.

Experimental data were computer-fit to this equation to obtain $k_{1}, k_{2}$, and $k_{3}$ by using the least squares method of grids as previously described $(22,23)$. The coefficient of variation of the fit was quantitated as

$$
\frac{\sum_{i=1}^{n}\left(\log \exp _{i}-\log \operatorname{calc}_{i}\right)^{2} /(n-3)}{(1 / n) \sum_{i=1}^{n} \log \exp _{i}},
$$

where $n$ is the total number of data points, $\exp _{t}$ is the experimentally observed value at point $i$, and calc $c_{i}$ is the corresponding calculated value.

Removal of bilirubin from the perfusate does not necessarily imply that it is metabolized and excreted normally by the hepatocyte. For this reason, biliary excretion of $\left[{ }^{3} \mathrm{H}\right]-$ bilirubin was determined in perfused liver in which biliary catheters were placed. After injection of $10 \mathrm{nmol}$ of $\left[{ }^{3} \mathrm{H}\right]$ bilirubin/ ${ }^{125} \mathrm{I}$-albumin $(1: 1)$ or $10 \mathrm{nmol}$ of $\left[{ }^{3} \mathrm{H}\right]$ bilirubin and $\left[{ }^{14} \mathrm{C}\right]$ sucrose, bile was collected in tared vials at $10-\mathrm{min}$ intervals for $1 \mathrm{~h}$ and radioactivity was determined.

Data were also analyzed in a model-independent fashion by calculating the total amount of bilirubin removed by the liver in a single 40-s pass as a percentage of that injected. Spaces of distribution of $\left[{ }^{14} \mathrm{C}\right]$ sucrose and ${ }^{125}$ I-albumin were calculated as the product of flow and mean transit time (7).

\section{RESULTS}

In all experiments, perfused livers remained viable during the course of the study as judged by constant perfusate flow $(1.9 \pm 0.2 \mathrm{ml} / \mathrm{min}$ per $\mathrm{g}$ liver; mean $\pm S E M)$, perfusion pressure $\left(13 \pm 1.2 \mathrm{~cm} \mathrm{H}_{2} \mathrm{O}\right)$, perfusate $\mathrm{pH}(7.44 \pm 0.01)$, and arteriovenous $\mathrm{Po}_{2}$ difference $(399 \pm 8 \mathrm{mmHg})$. Hepatic oxygen consumption was $1.48 \pm 0.08 \mu \mathrm{mol} / \mathrm{g}$ per min. During the course of 
TABLE I

Perfused Liver Uptake of $\left[{ }^{3} \mathrm{H}\right]$ Bilirubin after Injection as an Equimolar Complex with ${ }^{125} \mathrm{I}-$ Albumin or ${ }^{125}$ I-Ligandin or Free with a $\left[{ }^{14} \mathrm{C}\right]$ Sucrose Reference

\begin{tabular}{|c|c|c|c|c|c|c|c|}
\hline $\begin{array}{c}{\left[{ }^{s} \mathrm{H}\right] \text { Bilirubin }} \\
\text { injected }\end{array}$ & Injected reference & $\begin{array}{l}\text { No. of } \\
\text { studies }\end{array}$ & $\begin{array}{c}{[\mathrm{s} H] \text { Bilirubin }} \\
\text { uptake }\end{array}$ & $\begin{array}{c}\text { Influx } \\
\left(k_{1}\right)\end{array}$ & $\begin{array}{c}\text { Efflux } \\
\left(k_{\mathbf{z}}\right)\end{array}$ & $\begin{array}{l}\text { Sequestration } \\
\qquad\left(k_{s}\right)\end{array}$ & $\begin{array}{l}\text { Coefficient of } \\
\text { variation of } \\
\text { computer fit }\end{array}$ \\
\hline nmol & & & $\%$ of injected & $s^{-1} \times 10^{-2}$ & $s^{-1} \times 10^{-2}$ & $s^{-1} \times 10^{-8}$ & $\times 10^{-8}$ \\
\hline 1 & ${ }^{125}$ I-Albumin (1:1) & 3 & $71.7 \pm 6.5$ & $12.9 \pm 1.5$ & $3.5 \pm 0.9$ & $7.6 \pm 0.9$ & $1.82 \pm 0.13$ \\
\hline 1 & {$\left[{ }^{14} \mathrm{C}\right]$ Sucrose } & 8 & $69.4 \pm 2.5$ & $15.1 \pm 1.9$ & $4.5 \pm 0.4$ & $7.0 \pm 0.6$ & $1.54 \pm 0.09$ \\
\hline 10 & ${ }^{125}$ I-Albumin $(1: 1)$ & 12 & $67.5 \pm 3.7$ & $11.9 \pm 1.0^{\circ}$ & $2.5 \pm 0.4$ & $8.2 \pm 0.6$ & $1.59 \pm 0.26$ \\
\hline 10 & ${ }^{125} \mathrm{I}$-Ligandin $(1: 1)$ & 5 & $67.4 \pm 6.5$ & $15.7 \pm 3.6$ & $5.1 \pm 0.7$ & $6.8 \pm 1.2$ & $1.98 \pm 0.19$ \\
\hline 10 & {$\left[{ }^{14} \mathrm{C}\right]$ Sucrose } & 13 & $74.9 \pm 2.4$ & $19.8 \pm 1.6$ & $3.1 \pm 0.3$ & $7.5 \pm 0.3$ & $1.51 \pm 0.10$ \\
\hline 200 & ${ }^{125}$ I-Albumin (1:1) & 3 & $46.4 \pm 3.1 \ddagger \S$ & $8.5 \pm 1.3 !$ & $1.7 \pm 0.3$ & $6.5 \pm 0.2$ & $1.21 \pm 0.09$ \\
\hline 200 & {$\left[{ }^{14} \mathrm{C}\right]$ Sucrose } & 5 & $63.3 \pm 3.4^{\bullet}$ & $13.5 \pm 1.0^{\circ}$ & $2.9 \pm 0.2$ & $8.2 \pm 0.5$ & $1.46 \pm 0.10$ \\
\hline
\end{tabular}

- $P<0.01$ compared with $\left[{ }^{14} \mathrm{C}\right]$ sucrose $/ 10 \mathrm{nmol}\left[{ }^{3} \mathrm{H}\right]$ bilirubin.

$\ddagger P<0.02$ compared with $\left[{ }^{14} \mathrm{C}\right]$ sucrose $/ 200 \mathrm{nmol}\left[{ }^{3} \mathrm{H}\right]$ bilirubin.

$\$ P<0.01$ compared with ${ }^{125} \mathrm{I}$-albumin $/ 10 \mathrm{nmol}\left[{ }^{3} \mathrm{H}\right]$ bilirubin.

perfusion, aspartate aminotransferase activity in perfusate did not rise and averaged 16.6 \pm 3.5 Karmen units/ml. In 18 studies, recovery of ${ }^{125} \mathrm{I}$-albumin was $95.6 \pm 1.0 \%$ of the injected dose. In 26 studies, recovery of $\left[{ }^{14} \mathrm{C}\right]$ sucrose was $97.3 \pm 1.4 \%$. In five studies, recovery of ${ }^{125} \mathrm{I}$-ligandin was $91 \pm 4.3 \%$.

Results of studies of hepatic $\left[{ }^{3} \mathrm{H}\right]$ bilirubin transport are summarized in Table I. At none of the three bilirubin concentrations was binding to albumin associated with enhanced total hepatic uptake or influx of $\left[{ }^{3} \mathrm{H}\right]$ bilirubin (Figs. 1 and 2 ). $\left[{ }^{3} \mathrm{H}\right]$ Bilirubin injected bound to ${ }^{125} \mathrm{I}$-ligandin was removed from perfusate as well as $\left[{ }^{3} \mathrm{H}\right]$ bilirubin injected bound to ${ }^{125} \mathrm{I}$-albumin $(P>0.2)$, which suggests that there is no carrier-protein specificity for bilirubin uptake. At the highest bilirubin concentration ( $200 \mathrm{nmol} /$ injection), net uptake of $\left[{ }^{3} \mathrm{H}\right]$ bilirubin injected as a complex with ${ }^{125} \mathrm{I}$ albumin was reduced as compared to results at lower concentrations $(P<0.02)$. Although influx also tended to be lower, results were not statistically significant $(P=0.15)$. Net uptake and influx of $200 \mathrm{nmol}$ of $\left[{ }^{3} \mathrm{H}\right]$ bilirubin injected unbound to protein was also significantly lower than that at $10 \mathrm{nmol}(P<0.01)$. At each of the three bilirubin concentrations studied, efflux and sequestration rates were comparable, except for significantly increased efflux when $\left[{ }^{3} \mathrm{H}\right]$ bilirubin was administered bound to ${ }^{125}$ I-ligandin $(P<0.005)$.

Ellipticity peaks of albumin-bilirubin at 405 and 475 $\mathrm{nm}$ were within $15 \%$ of that predicted by $50 \%$ dilution with fluorocarbon. Bilirubin in fluorocarbon did not generate ellipticity. These results suggested that the albumin-bilirubin complex remained intact in fluorocarbon. The space of distribution of $\left[{ }^{14} \mathrm{C}\right]$ sucrose in the studies, as presented in Table $I$, was $0.35 \pm 0.013$ $\mathrm{ml} / \mathrm{g}$ liver. This was significantly greater $(P<0.002)$ than the space of distribution of ${ }^{125} \mathrm{I}$-albumin $(0.30 \pm 0.008 \mathrm{ml} / \mathrm{g}$ liver $)$. In two studies, $10 \mathrm{nmol}$ of $\left[{ }^{3} \mathrm{H}\right]$ bilirubin was injected with equimolar ${ }^{125} \mathrm{I}$-albumin to which $\left[{ }^{14} \mathrm{C}\right]$ sucrose was added as a second reference (Fig. 3). There was no delay in ${ }^{125} \mathrm{I}$-albumin transit time as compared with that of $\left[{ }^{14} \mathrm{C}\right]$ sucrose. The normalized outflow curve of ${ }^{125} \mathrm{I}$-albumin was slightly ahead of that of $\left[{ }^{14} \mathrm{C}\right]$ sucrose, as might be expected because of its higher molecular weight, which results in a smaller space of distribution (17).

Biliary excretion of $10 \mathrm{nmol}$ of $\left[{ }^{3} \mathrm{H}\right]$ bilirubin was identical after injection with equimolar ${ }^{125} \mathrm{I}$-albumin or with a $\left[{ }^{14} \mathrm{C}\right]$ sucrose reference. At $60 \mathrm{~min}$ after injection, $70.5 \pm 4.6 \%$ and $69.5 \pm 3.2 \%$ of $\left[{ }^{3} \mathrm{H}\right]$ bilirubin removed by the liver was recovered in bile, respectively.

\section{DISCUSSION}

Bilirubin uptake by the liver is a rapid process of high specificity that has kinetic characteristics which suggest carrier-mediation $(3,5)$. The nature of the carrier is unknown, although several candidates have been identified and purified from rat liver cell plasma membrane preparations (24-26).

In the circulation, bilirubin is readily bound to albumin, from which it is extracted by the liver (5-7, $22,23)$. Several studies with bilirubin and bromosulphthalein (BSP) ${ }^{1}$ suggested that it is the small, unbound fraction which interacts with hepatocytes, re-

\footnotetext{
${ }^{1}$ Abbreviation used in this paper: BSP, bromosulphthalein.
} 


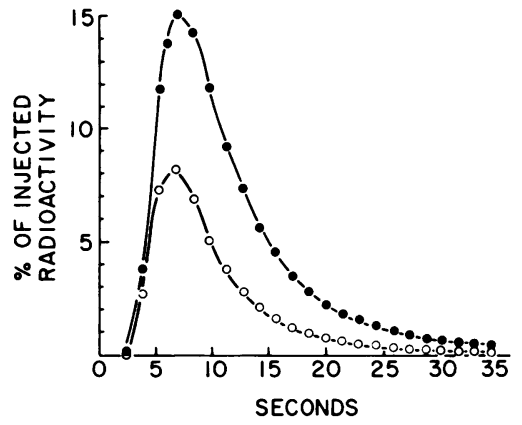

Figure 1 Typical outflow dilution curves for ${ }^{125} \mathrm{I}$-albumin (O) and $\left[{ }^{3} \mathrm{H}\right]$ bilirubin $(O)$ when injected as an equimolar complex into fluorocarbon-perfused rat liver. Each point represents the percent of injected radioactivity collected in a vial at the indicated time. In this experiment, recovery of ${ }^{125} \mathrm{I}$-albumin was $103 \%$ and of $\left[{ }^{3} \mathrm{H}\right]$ bilirubin $47 \%$ of the respective injected dose.

sulting in its removal from the circulation. Brauer and Pessotti (27) determined that, with increased concentration of BSA, BSP uptake by rat liver slices is reduced. In hypoalbuminemic patients (13), there is a reciprocal relationship between plasma albumin concentrations and hepatic BSP uptake. Similarly, in isolated perfused rat liver, influx of dibromosulphthalein is enhanced when albumin concentrations are reduced (28). Using an ultracentrifugation method to estimate free bilirubin, Barnhart and Clarenburg suggested that a single clearance constant for free bilirubin was sufficient to describe hepatic bilirubin uptake and found that constant to be independent of the circulating albumin level $(10,11)$.

This concept has recently been challenged. Luxon and Forker studied taurocholate uptake by isolated rat

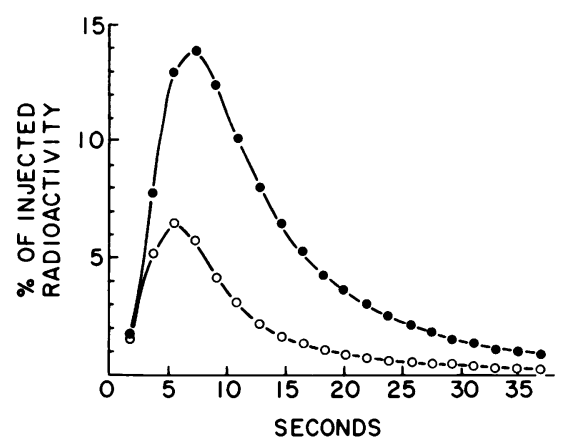

Figure 2 Typical outflow dilution curve for $\left[{ }^{14} \mathrm{C}\right]$ sucrose $(\bullet)$ and $\left[{ }^{3} \mathrm{H}\right]$ bilirubin $(\mathrm{O})$ in fluorocarbon-perfused rat liver. Each point represents the percent of injected radioactivity collected in a vial at the indicated time. Similar to results with ${ }^{125} \mathrm{I}$-bilirubin, recovery of $\left[{ }^{14} \mathrm{C}\right]$ sucrose was $107 \%$ and of $\left[{ }^{3} \mathrm{H}\right]$ bilirubin $39 \%$ of the respective injected dose.

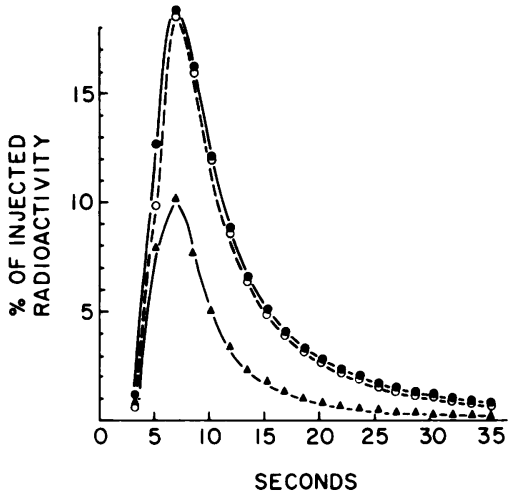

Figure 3 Outflow dilution curves for ${ }^{125}$ I-albumin (๑), $\left[{ }^{14} \mathrm{C}\right]$ sucrose $(\mathrm{O})$, and $\left[{ }^{3} \mathrm{H}\right]$ bilirubin $(\Delta)$ when injected simultaneously into a fluorocarbon-perfused rat liver. Each point represents the percent of injected radioactivity collected in a vial at the indicated time. There is no delay in transit of ${ }^{125} \mathrm{I}$-albumin as compared with $\left[{ }^{14} \mathrm{C}\right]$ sucrose. In this study, recovery of ${ }^{125} \mathrm{I}$-albumin was $104 \%$; $\left[{ }^{14} \mathrm{C}\right]$ sucrose, $103 \%$; and $\left[{ }^{3} \mathrm{H}\right]$ bilirubin, $46 \%$.

liver perfused with buffer containing 0.5 or $5 \%$ BSA (14). They determined free ligand by equilibrium dialysis of perfusate. Increasing albumin from 0.5 to $5.0 \%$ was sufficient to reduce the concentration of free taurocholate fivefold, but this also resulted in only a twofold reduction in hepatic uptake. On the basis of these studies, they postulated that albumin interacts with the hepatocyte surface and accelerates the release of taurocholate, which facilitates its subsequent uptake. In other studies, Weisiger et al. investigated the influence of BSA on transport by the isolated rat liver perfused with fluorocarbon after perfusion with albumin-containing buffer (16). At a fixed albumin concentration, oleate uptake does not saturate, whereas uptake of a 1:1 molar complex of oleate and albumin is saturable, despite a nearly constant concentration of free oleate. They postulated a liver cell surface receptor for albumin which "catalyzes" the uptake of albumin-bound oleate. Similar conclusions were reached in studies of hepatic uptake of bilirubin and BSP (15).

The results of the present study indicated that hepatic uptake of bilirubin over a 200-fold range of concentration does not require binding to albumin. Uptake of $\left[{ }^{3} \mathrm{H}\right]$ bilirubin that was injected bound to ${ }^{125} \mathrm{I}-$ ligandin was as rapid as that injected bound to ${ }^{125} \mathrm{I}$ albumin. Ligandin is normally an intracellular protein that binds bilirubin with high affinity and is distinct from albumın (19). These findings do not preclude interaction of the bilirubin-carrier complex with the liver cell, but suggest that there is no carrier-protein specificity for bilirubin uptake.

Weisiger et al. (15) reported saturation of uptake 
only when ligand is bound to albumin. Their studies were performed during constant infusion of ligand at steady state net uptake (16); the highest bilirubin concentration that they studied was $100 \mu \mathrm{M}$ (15). Our single-pulse studies revealed reduced influx and net extraction of both albumin-bound and free bilirubin injected at $200 \mathrm{nmol} / 0.16 \mathrm{ml}$ as compared with results at lower doses. This suggested that, at the highest concentration of bilirubin we studied $(1.25 \mathrm{mM})$, uptake of bilirubin was saturable whether or not it is bound to albumin.

Because disappearance of bilirubin from perfusate does not imply that uptake into the hepatocyte has occurred, we studied biliary excretion of $\left[{ }^{3} \mathrm{H}\right]$ bilirubin. These studies revealed that bilirubin was excreted into bile at the same rate, whether it was injected bound to albumin or free. These studies provided no basis for hypothesizing facilitation by albumin of hepatic bilirubin uptake. That there is no evidence for interaction of albumin with a liver cell surface receptor is revealed by other studies. The space of distribution of $\left[{ }^{14} \mathrm{C}\right]$ sucrose was significantly greater than that of ${ }^{125} \mathrm{I}$ albumin. When ${ }^{125} \mathrm{I}$-albumin $/\left[{ }^{3} \mathrm{H}\right]$ bilirubin (1:1 molar ratio) was injected with $\left[{ }^{14} \mathrm{C}\right]$ sucrose, there was no delay in albumin transit. These findings suggested a rapid off-rate of albumin from its putative hepatocyte receptor, which is unusual for high affinity receptor-ligand interaction. These results conflict with studies of Weisiger et al., (16) in which they suggested high capacity $\left(10^{7}\right.$ binding sites/cell) binding of albumin to isolated hepatocytes. Although it is possible in our studies that fluorocarbon interfered with the interaction of albumin and its receptor, this seems unlikely; similar results have been reported in livers perfused with standard albumin-containing perfusate (17).

The data in the present study revealed that albuminbinding was not necessary for the rapid uptake, metabolism, and biliary excretion of bilirubin by the liver. There was no facilitation of bilirubin uptake by albumin-binding over a 200 -fold concentration range. An alternative hypothesis proposed by Weisiger et al. (16) is the presence of high-affinity, low-capacity and low-affinity, high-capacity bilirubin binding sites on the liver cell surface. Our data also suggested that the hepatic bilirubin uptake mechanism is one of high affinity for this ligand, and that it has the ability to extract it nonspecifically from circulating carriers such as albumin, ligandin, or fluorocarbon.

\section{ACKNOWLEDGMENT}

The authors would like to acknowledge the gift of Fluosol43 from Alpha Therapeutics Corp., Santa Ana, CA.

This work was supported by National Institutes of Health grants AM-23026, AM-17702, AM-32419, and AM-02019.

\section{REFERENCES}

1. Kamisaka, K., I. Listowsky, J. J. Betheil, and I. M. Arias. 1974. Competitive binding of bilirubin, sulfobromophthalein, indocyanine green and other organic anions to human and bovine serum albumin. Biochim. Biophys. Acta. 365:169-180.

2. Gray, R. D., and S. S. Stroupe. 1978. Kinetics and mechanism of bilirubin binding to human serum albumin. $J$. Biol. Chem. 253:4370-4377.

3. Scharschmidt, B. F., J. G. Waggoner, and P. D. Berk. 1975. Hepatic organic anion uptake in the rat. J. Clin. Invest. 75:1280-1292.

4. Wolkoff, A. W., J. N. Ketley, J. G. Waggoner, P. D. Berk, and W. B. Jakoby. 1978. Hepatic accumulation and intracellular binding of conjugated bilirubin. J. Clin. Invest. 61:142-149.

5. Goresky, C. A. 1975. The hepatic uptake process: its implications for bilirubin transport. In Jaundice. C. A. Goresky and M. M. Fishers, editors. Plenum Press, New York. 159-174.

6. Goresky, C. A. 1965. The hepatic uptake and excretion of sulfobromophthalein and bilirubin. Can. Med. Assoc. J. 92:851-857.

7. Wolkoff, A. W., C. A. Goresky, J. Sellin, Z. Gaitmaitan, and I. M. Arias. 1979. Role of ligandin in transfer of bilirubin from plasma into liver. Am. J. Physiol. 236:E638-E648.

8. Bloomer, J. R., P. D. Berk, J. Vergalla, and N. I. Berlin. 1973. Influence of albumin on the hepatic uptake of unconjugated bilirubin. Clin. Sci. Mol. Med. 45:505516.

9. Bloomer, J. R., P. D. Berk, J. Vergalla, and N. I. Berlin. 1973. Influence of albumin on the extravascular distribution of unconjugated bilirubin. Clin. Sci. Mol. Med. 45:517-526.

10. Clarenburg, R., and J. L. Barnhart. 1973. Interactions of serum albumin and bilirubin at low concentrations. Am. J. Physiol. 225:493-496.

11. Barnhart, J. L., and R. Clarenburg. 1973. Factors determining clearance of bilirubin in perfused rat liver. Am. J. Physiol. 225:497-507.

12. Oie, S., and G. Levy. 1975. Effect of plasma protein binding on elimination of bilirubin. J. Pharm. Sci. 64:1433.

13. Grausz, H., and R. Schmid. 1971. Reciprocal relation between plasma albumin level and hepatic sulfobromophthalein removal. N. Engl. J. Med. 284:1403-1406.

14. Luxon, B. A., and E. L. Forker. 1981. Albumin helps mediate removal of taurocholate by rat liver. J. Clin. Invest. 67:1517-1522.

15. Weisiger, R., J. Gollan, and R. Ockner. 1980. An albumin receptor on the liver cell may mediate hepatic uptake of sulfobromophthalein and bilirubin: bound ligand, not free, is the major uptake determinant. Gastroenterology. 79:1065. (Abstr.)

16. Weisiger, R., J. Gollan, and R. Ockner. 1981. Receptor for albumin on the liver cell surface may mediate uptake of fatty acids and other albumin-bound substances. Science (Wash. DC). 211:1048-1051.

17. Goresky, C. A. 1963. A linear method for determining liver sinusoidal and extravascular volumes. Am. J. Physiol. 204:626-640.

18. Howe, R. B., P. D. Berk, J. R. Bloomer, and N. I. Berlin. 1970. Preparation and properties of specifically labeled radiochemically stable ${ }^{3} \mathrm{H}$-bilirubin. J. Lab. Clin. Med. 75:499-502. 
19. Fleischner, G., J. Robbins, and I. M. Arias. 1972. Immunological studies of $\mathrm{Y}$ protein. A major cytoplasmic organic-anion binding protein in rat liver. J. Clin. Invest. 51:677-684.

20. Greenwood, F. C., W. M. Hunter, and J. S. Glover. 1963. The preparation of ${ }^{131} I$-labelled human growth hormone of high specific radioactivity. Biochem. J. 89:114-123.

21. Goresky, C. A., and G. G. Bach. 1970. Membrane transport and the hepatic circulation. Ann. NY Acad. Sci. 170:18-47.

22. Gärtner, U., R. J. Stockert, A. G. Morell, and A. W. Wolkoff. 1981. Modulation of the transport of bilirubin and asialoorosomucoid during liver regeneration. $\mathrm{He}$ patology (Baltimore). 1:99-106.

23. Gärtner, U., R. J. Stockert, W. G. Levine, and A. W. Wolkoff. 1982. Effect of nafenopin on the uptake of bilirubin and sulfobromophthalein by isolated perfused rat liver. Gastroenterology. 83:1163-1169.

24. Tiribelli, C., G. Lunazzi, G. L. Luciani, E. Panfili, B. Gazzin, G. Liut, G. Sandri, and G. Sottocasa. 1978. Iso- lation of a sulfobromophthalein-binding protein from hepatocyte plasma membrane. Biochim. Biophys. Acta. 532:105-112.

25. Reichen, J., and P. D. Berk. 1979. Isolation of an organic anion binding protein from rat liver plasma membrane fractions by affinity chromatography. Biochem. Biophys. Res. Commun. 91:484-489.

26. Wolkoff, A. W., and C. T. Chung. 1980. Identification, purification, and partial characterization of an organic anion binding protein from rat liver cell plasma membrane. J. Clin. Invest. 65:1152-1161.

27. Brauer, R. W., and R. L. Pessotti. 1949. The removal of bromsulphthalein from blood plasma by the liver of the rat. J. Pharmacol. Exp. Ther. 97:358-370.

28. Meijer, D., R. J. Vonk, K. Keulemans, and J. G. Weitering. 1977. Hepatic uptake and biliary excretion of dibromosulphthalein. Albumin dependence, influence of phenobarbital and nafenopin pretreatment and the role of $Y$ and $Z$ protein. J. Pharmacol. Exp. Ther. 202:8-21. 